УДК 330.14.012

JEL: O34, D24, D83, J24, L14, M14

Litvinov Oleksandr

PhD (Economics), Assistant Professor Assistant Professor of Department of Economics of Enterprise and business organization

Odessa National Economic University

(Odesa, Ukraine)

Nefedova Tamara

PhD (Finance), Assistant Professor of Finance

University Paris-Dauphine

(Paris, France)

\title{
MARKETING AS THE SOURCE OF ESTABLISHMENT OF PILLARS OF THE ENTERPRISE INTELLECTUAL CAPITAL
}

The article analyzes the development of ideas about the composition of intellectual capital and the place of marketing as its source. The key problem is determining the list of features by which the classification of intellectual capital components will be formed. On the basis of a critical analysis of the existing classifications of intellectual capital components, the author's classification was formed on the following grounds: by sources of formation; by subjects or carriers; by functional content; depending on the origin; depending on the degree of controllability; by scope; on the principle of belonging of elements; depending on the stage of the play cycle; depending on the dynamics of their wear and play; by way of storing information; in relation to the process of creating new objects; depending on the degree of identification

Keywords: intellectual capital, intellectual capital elements, human capital, capital of relations, organizational capital, marketing.

\section{DOI: $10.15276 / \mathrm{mdt} .3 .3 .2019 .2$}

Statement of the problem in general form and it's connection with important scientific or practical tasks. In recent years, intangible components of activity have become increasingly important in the enterprises activity. The transition of the economy from the material form of development to the intangible M. Oklander called the formation of information economy, ie economy in which the main driver of growth is knowledge [1]. Knowledge becomes the main part of the enterprise capital and the term intellectual capital (hereinafter IC) is used to identify them.

By IC we propose to understand the set of socio-economic relationships that are associated with the formation, usage and restoration of knowledge. An important task is to establish a classification of IC components that would allow them to be identified, evaluated and managed.

Analysis of the latest research and publications, which initiated the solution of this problem and on which the author relies. Since the first use of IC as a scientific category, namely T. Stewart in 1991, scientists have begun active discussions to determine its components.

(C) 2019 The Authors. This is an open access article under the CC BY license (http://creativecommons.org/licenses/by/4.0) 
In 1993, G. St Onge formed the classification of IC, which became a classic, dividing IC into human, client, and structural capital [2].

K. Swabey included customer relations in the IC classification [3].

L. Edwinsson, M. Malone have developed a classification of IC, consisting of human and structural capital [4]. They combined internal and external company structures into structural capital, namely, relationship capital (reputation, trademark, regular customers, distribution channels) and organizational capital, which in turn was divided into innovation capital (intellectual property (hereinafter - IP) and other intangible assets (hereinafter referred to as IA) and process capital (organizational culture and structure, databases, information networks).

And Brooking expanded the components of IC by adding to its human-centered and infrastructure assets also market assets and assets related to IP [5, p. 13].

N. Bonti believed that IC consists of 3 parts: human, organizational, consumer [6, p. 64]. Namely, it increased attention to consumer-related knowledge but excluded other external relations (with partners, suppliers, the state) from the list.

B. Lev, F. Gu in IC allocated 5 groups of intangibles: R\&D; advertising; intangibles that are included into the capital of the enterprise; information systems; technology acquisition [7, p. 14]. The focus is on advertising, but advertising is a means of conveying information to enhance the elements of IC (reputation, image, technology, social responsibility, corporate culture) and material capital (quality and price of products). If advertising was IC by itself, businesses could replace it with all other elements. Indeed, advertising serves not only the transmission of information, but also the formation of demand, improving the reputation and image of the company, increasing customer loyalty. Therefore, it is important to consider advertising as one of the main means of reproducing the level of development of components of the enterprise IC.

A group of Indian scientists proposed to divide the IC into 6 components: human, consumer, structural, social, technological, spiritual capital [8]. However, no attention was paid to the objects of IP as an element of IC.

Highlighting the previously unresolved parts of the general problem to which the article is devoted. Despite the large number of studies that have focused on the isolation of IC constituents, a common vision has not been formed yet, not only of IC constituents, but also of the classification features by which they could be structured. Since the notion of IP and goodwill has become widespread prior to the emergence of IC, there is a particular need for determining their place in the IC of an enterprise. Also the problems of establishing the place and role of marketing in the IC classification system are unresolved.

Formulation of the purpose of the article (statement of the problem). The purpose of the article is to form a system of classification features and relevant components of IC with determining the place and role of marketing as a source of IC.

Statement of the main material of the research with full justification of the scientific results obtained. Ownership is the subject's right to own, use and dispose of the property. IP is then the subject's right to own, use and dispose of the result of intellectual activity (or IC). Thus, IP is a legal envelope to protect and secure legal rights to dispose of IC components. The problem is that not all IC constituents can be granted legal rights, as ICs are intangible in nature and most of their constituents cannot be identified and legally protected. Therefore, the objects of IP are some of the most materialized components of IC, which belong to its diverse species. For example, trademarks and trade names are tending to be the legal embodiment of a constituent of client capital, which is to protect the appearance of the product and business name, and the patent is to protect technological capital in the form of some innovation, invention. A brand cannot be regarded as a trademark that is registered and has

O. Litvinov, T. Nefedova. Marketing as the source of establishment of pillars of the 17 enterprise intellectual capital 
legal rights. The brand is the result of marketing influence in order to perceive a brand, a set of product properties and other actions of the enterprise by environmental actors, primarily consumers of products. That is, the brand is the result of the relationship of the company with its external environment, which causes the inclusion of the brand, reputation, image of the company in the capital of the relationship. The source of these relationships is marketing, as an activity aimed at shaping the optimum impact on consumers and other environmental actors.

However, the need to study the objects that are protected by IP law from the subject of economic research of the processes of their reproduction cannot be dismissed. Therefore, further research would use non-legal terminology to characterize the IC object, but economic terminology that characterizes the content of the IC object (instead of patent - invention, innovation; not trademark, but brand, client capital; not license, and the capital of relations with state authorities; not leases, franchises, but partnership capital).

The US Financial Accounting Standards Board (FASB) has approved seven categories of an enterprise's IS that relate to [8]:

- current regulatory framework;

- contracts;

- technologies;

- labor resources;

- features of the organization;

- consumers;

- market opportunities.

The FASB's recommendations are reflected in international accounting standards. The FASB has proposed to significantly expand the composition of the company's IS by including such components of goodwill, $\mathrm{R} \& \mathrm{D}$ and certain types of marketing assets and, as a consequence, the ability to replenish them using amortization.

It should be noted that many contemporary authors do not include goodwill in the IC, although it is currently presented in international and almost all national accounting standards. The exclusion of goodwill from the elements of IC is explained by the fact that goodwill was introduced into economic and accounting terminology as an attempt to explain the gap between market and book values of enterprises. As you know, goodwill could only be entered in the balance sheet of an enterprise if the enterprise was acquired. It could not be created on its own or bought or sold. That is, goodwill was put into circulation in order to temporarily reflect the difference between the book value and the market price of the enterprise, and not to actually enable the inclusion of new types of IS into the assets of the enterprise. Goodwill's economic content is a reputation, the image of which the marketing activity of the enterprise acts as a source. Therefore, in modern research, to avoid confusion with outdated accounting standards, most scientists either do not use goodwill as a component of IC, or have replaced this concept with the image and reputation of the enterprise.

That is, a number of components of IC, namely, brand, goodwill, reputation, image, client capital, social capital and in general, the capital of the enterprise relations are the result of the marketing activity of the enterprise, which makes marketing the determining source of IC formation. Other sources of IC components include: human resource management activities - generates human capital; R\&D, innovation - generates intellectual and technological capital; organizational activity - forms the structural capital of the enterprise.

Particular consideration should be given to the usage of $R \& D$, or abbreviated $R \& D$, among types of IC. In the post-Soviet space, this term is often used in the format of research and development (R\&D). R\&D is a major source of IC creation and restoration. Since IC is currently the main engine for creating competitive advantage and increasing the market value 
of enterprises, $R \& D$ costs have taken the lead role in the investment spheres of economically developed countries in the worldwide. Particular attention should be paid to R\&D in terms of their decisive influence on the reproduction of IC enterprises. But R\&D, in our opinion, can not be attributed to a separate subspecies of IC, since scientific research is a source of knowledge of various kinds, which will eventually be embodied in human capital, technology, customer relations and other entities in the formation of corporate norms and standards for both: business and social behavior. In other words, $R \& D$ is a means of forming all components of IC, but do not directly its component.

It is worth noting the proposal of O. Shkurupi to allocate in the IC of its active and passive parts. The active part of IC is represented by the human capital of individuals, while the passive IC is an intellectual product, that is, put into practice ideas that are available for use and evaluation by other actors. The passive component represents technologies, processes, inventions, trademarks, etc. [10, p. 16-17]. We cannot accept the inclusion of intellectual products in the passive part of IC as they are a confirmation of the public utility of using the IC enterprise. From the cost point of view of IC at the stage of formation and creation is in the form of investment in new objects of IC, at the stage of demolition - in the form of existing objects of IC and at the stage of reproduction - in the form of return on investment through the sale (lease) of intellectual (in varying degrees) of products. At the same time, most modern industries use elements of IC, which indicates its involvement in the creation of new value, which, as a result of demand, will have signs of socially necessary costs. Thus, the sale (lease) of products produced with the use of IC elements is a stage of the IC reproduction process, and the intellectual product is an alienated part of all components of the IC, not its variety.

Next, let's look at the features of incorporating the most common elements of scientists into human resources: human, structural, social, technological, client capital, as well as information and databases.

V. Schultz, Nobel Prize winner, one of the founders of the theory of human capital, stated that the decisive factors in economic development and improvement of the well-being of the population are not energy, space or agriculture, but rather the improvement of the level of knowledge and education [11]. Human capital is crucial to the enterprise.

It is due to human capital that the enterprise can ensure the reproduction of both activity and individual resources, as well as innovative development. Human capital is the main source of creation of other types of IC and represents the knowledge and skills of the workforce of the enterprise. In the study of human capital, a moral dilemma arises as enterprise staff is the most important resource of enterprises, but it is not its property. Can an enterprise claim to control the knowledge, skills of its personnel? Does human capital meet the requirement to benefit the enterprise in the future? In general, some authors have drawn attention to the contradictions inherent in the concept of "human capital", namely, that it is intertwined between the opposites: labor and capital. As a result, it seems that everyone is a capitalist.

In our opinion, although the term "human capital" is coined with the usage of opposite concepts, it only emphasizes the realities of development of modern society, when knowledge becomes the main resource of entrepreneurial activity. In terms of the classic requirement of long-term useful usage of any capital, it can be noted that investing in the development of enterprise personnel, that is, human capital, can bring long-term positive results.

As D. Roos, G. Roos, N. Dragonetti and L. Edwinson have aptly defined, structural capital can be represented as what remains at the enterprise after the workers go home, as what glues all the enterprise resources into a single organism. [12]. Structural capital is a critical link that makes it possible to identify all other elements of an enterprise's IC; without a structural capital, as without a spine, the enterprise would not be able to function. The structure of the structural capital includes attribution of knowledge carriers of the enterprise (with the exception

O. Litvinov, T. Nefedova. Marketing as the source of establishment of pillars of the 19 enterprise intellectual capital 
of personnel): databases, processes, organizational structure, policy and organization of performance of functions by personnel (all types of internal provisions, regulations and internal guidelines for the performance of functions). However, in our opinion, combining structural organizational and technological components within the structural capital only complicates the process of IC classification.

Particular attention should be paid to databases as a possible element of IC, which is a technical means of accumulating information that aims to replace the natural composition of information - human beings. Man has learned to store and transmit information through various forms of his record, which ensured its accumulation and use it on a growing scale, but the invention of electronic drives and their evolution have turned this process into an explosive one. However, it is not possible to distinguish databases as a classification group of objects of an enterprise IC, since information, knowledge comprises all elements of an IC, and databases must be used to store, process and transmit information. That is, a database is a technical means of forming all components of IC, not its kind. In general, information is not a separate kind of IC, but a means of transforming, storing and transmitting knowledge of all kinds.

$\mathrm{K}$. Corrado et al. thinks that a software and computer information within an enterprise IC plays the key role [13]. Of course, software plays an important role in enterprise activity, but it is only one of the tools of enterprises activity.

Some authors quite rightly allocate technological capital separately - knowledge that already takes the form of material objects and tools implemented in the material form. E. Bueno et al. attributes to technological capital those technological processes that are based on innovation [14].

One of the important elements of an enterprise's IC is its social capital, or capital of relations with society, which is formed through the marketing activity of the enterprise.

O. Sobko divided all components of IC into individual IC, collective IC, social IC [15, p. 317]. External social capital is represented by relations with society, the reputation of the enterprise, the attitude of the enterprise to the problems of society, to the environment. Internal social capital can be characterized as the relation of the enterprise with the labor collective, the level of remuneration, social guarantees and support of the personnel of the enterprise.

In the question of capital inclusion of relations in the structural, organizational, process, or in the allocation of it as a separate component of IC, there is a constant discussion, so we will pay attention to this problem as well. You should pay attention to the relationship of the company with its customers, which is manifested in marketing activities. As consumers are the part of society, the question arises: do they relate to consumers with social capital, or are they a separate component of IC? Because consumers or demand are a key component of a market economy, many scholars include client capital as a separate component of an enterprise's IC.

$\mathrm{N}$. Bonti proposed to integrate within the client capital all the knowledge that is embodied in the relations of the company with the nearest external environment: with consumers, suppliers, investors, competitors, partners and state institutions [16]. As all these components of IC have a common essence - marketing relations between the enterprise and its immediate environment, including social relations, we suggest to include them in a common group, called the capital of relations.

As $\mathrm{O}$. Kendyukhov rightly pointed out, the main disadvantage of most IC classifications was the lack of a clear identification of the classification features by which it is proposed to divide IC [17, p. 44]. It identifies eleven classification features: scope; usage in production and commercial activity; ownership; features of functioning in the cycle of capital; directions of use; duration of use period; role in the production and economic process; conditions of formation; the possibility of alienation; the level of risk of usage; functional content $[17, \mathrm{p}$. 48-54]. While most of the classification features are of theoretical and practical importance, 
some are debatable. Such are, for example, the scope; the level of risk; the form of use in production and commercial activity - those in use, in development, in reserve, in conservation).

The main feature in the classification of IC by A. Kendyukhov is the allocation of IC by functional content: personified - those that are accepted by other authors to refer to human capital; infrastructure - information technology, databases, organizational structure, philosophy, management culture and business cooperation; technical and technological - those with engineering embodiment; client - relations and contracts with buyers, license agreements; branded IC - trade marks and marks, reputation [17, p. 53-54]. It should be noted that $\mathrm{O}$. Kendyukhov divided some of the same types of IC objects into functional subgroups. Thus, the relations with the buyers were separated from the relations with the partners, while the relations with the public and state bodies were not taken into account at all. Brand and client capital are justified, as they have different content, but the client capital includes licenses that result from interaction with the state, on the other hand the philosophy and culture of the company are separated from its reputation and image.

O. Butnik-Seversky divided IC by: ownership type, corporate transaction, residency, form of involvement, by the term of the entity's disposal, method of formation, possibility of determining value [18]. He used the approaches to the classification of classical capital with the purpose of interpreting them for distribution by types of IC, adding to them the author's attributes. He also paid too much attention to legally protected intellectual assets, combining all other types of IC into one group.

As a result of consideration of approaches to the definition of IC components, a classification of IC components has been proposed.

A key classification feature of an enterprise IC is the consideration of its elements by functional content. All elements of IC by this feature are divided into four groups: human capital, relationship capital, intellectual and technological capital, organizational (structural) capital. Human capital lies in the intellectual capacity of the company staff to achieve the goals of the enterprise. Relationship capital represents the totality of relationships with the nearest external environment that enable one to achieve the goals of the enterprise. Intellectualtechnological capital is a set of knowledge, which consists in engineering, software or design development, which enable to achieve the goals of the enterprise. Organizational capital represents a set of institutionalized knowledge, characteristics of the system of organization of activity and management of the enterprise and its reputation, which allow to achieve the goals of the enterprise. The proposed grouping of ICs is similar to the classical three-element, however, in our opinion, the distribution of IC components from the point of view of their origin on the external and internal should be deduced as a separate classification feature, and while grouping on the essential feature, we should stop at the above mentioned four types.

In addition to the classification of ICs based on their essential differences, it is important to distinguish components of ICs depending on the system of sources of formation. It is proposed to divide into IC elements, the source of which is:

- marketing activities - brand, reputation, image, customer, delivery, partnership, social and in general capital of the enterprise relations;

- activity of personnel management of the enterprise - selection, preparation, training, advanced training, motivation and stimulation of the enterprises personnel;

- innovation and $R \& D$ - the latest technologies, inventions and technical innovations, product and service design, artificial intelligence, software and information systems;

- organizational activity - organizational and production structure, corporate culture, management and communication system. 
By origin, IC consists of elements of IC that are created by the enterprise's own resources; elements of IC acquired from third parties; elements of IC that are received for temporary use on the basis of leases, franchising and other agreements for the use of IP.

By the type of the carrier entity, it is possible to distinguish country IC, enterprise IC, IC unit and IC entity.

Depending on the degree of control of the IC can be divided into: controlled IC, protected by legal means (in accounting controlled IC is commonly called the IS); uncontrolled IC that cannot be protected and incorporated into the assets of the enterprise.

In terms of the manifestation of the elements of IC can be divided into: external - client capital, supply capital, partnership capital, social capital, capital relations with the state; internal - experience, skills, competences, level of intelligence, intrinsic motivation, talent, talent, creativity and innovativeness of personnel, inventions and technical innovations, product and service design, know-how, software, organizational and production structure, corporate culture, management system and communications, procedures, manuals, brands, company image and reputation.

According to the principle of affiliation, the elements of IC can be divided into those that: belong to the enterprise - components of the capital of relations, technological and structural (organizational) capital; do not belong to the enterprise - components of human capital (since human capital is the characteristics of the personnel of the enterprise) and other objects of IC that may be in temporary use.

We suggest to consider the structure of IC, depending on what stage of the play cycle it is. The IC of the operating enterprise is in three stages of the reproduction cycle: the stage of formation-creation, the stage of wear, the stage of reproduction.

Also, we suggest to distinguish IC objects based on the features of wear and play dynamics - objects that have a high wear rate and require fast playback and objects that have a slow wear and play speed.

IR classification according to the way information is stored: natural sources of information (human); artificial media (books and other material media, digital media).

In relation to the process of creating new IC objects, we suggest to distinguish passive and active IC. Active IC can participate in its own reproduction or in the creation of new IC, while passive IC is a "fixed" result of the usage of IC, which would eventually lose its utility to the enterprise and would require the usage of other elements of IC for its reproduction. Depending on the degree of identification of IC could be divided into: identified, that is, described and measured in one way or another elements of IC; not identified, those not yet described and measured by the enterprise.

Conclusions from this research and prospects for further developments in this area. As a result of critical consideration of approaches to the definition of IC components, eleven classification features of the distribution of all IC elements have been identified. The key features of an enterprise IC are to consider its types by functional content and sources of formation. The functional content is divided into: human capital, capital of relations, intellectual-technological and organizational capital. Depending on the system of sources of formation, the elements of IC are divided into those whose source is: marketing, personnel management, innovation and organizational activity of the enterprise. It is substantiated that marketing is a source of formation of components of IC: brand, goodwill, reputation, image, client capital, social capital and in general the capital of relations of the enterprise. 
1. Oklander M. A., Lytovchenko I. L., Botushan M. I. (2011) Marketynhovi komunikatsii promyslovykh pidpryiemstv $v$ umovakh informatsiinoi ekonomiky [Marketing communication of industrial enterprises in the information economy]. Odesa: Astroprynt. (in Ukrainian).

2. Saint-Onge H. (1996) Tacit knowledge: the key to the strategic alignment of intellectual capital? Strategy and Leadership, vol. 24, no. 2, pp. 10-14.

3. Sveiby K. E. (1997) The New Organizational Wealth. San Francisco: CA.

4. Edvinsson L., Malone M. S. (1997) Intellectual Capital: Realizing your Company's True Value by Finding its Hidden Brainpower. New York: Harper Business.

5. Brooking A. (1997) Intellectual Capital: Core Asset for the Third Millennium Enterprise. Thomson Business Press, London.

6. Bontis N. (1998) Intellectual capital: an exploratory study that develops measures and models. Management Decision, vol. 36, no. 2, pp. 63-76.

7. Gu F, Lev B. (2001) Intangible assets - measurement, drivers, usefulness, working paper. New York: Boston University and New York University, NY.

8. Khalique M., Shaari J. A. N., Isa, A. H. b. M. (2013) The road to the development of intellectual capital theor. International Journal of Learning and Intellectual Capital, vol. 4, no. 2, pp. 122-136.

9. FASB NN. (2001) Getting a grip on intangible assets - what they are, why they matter, and who should be managing them in your organization. Harvard Management Update, vol. 6, no. 2, pp. 6-8.

10. Shkurupij O. V. (2010) Intelektual'nyj kapital v umovakh stanovlennia postindustrial'noho suspil'stva: imperatyvy hlobal'noho ekonomichnoho rozvytku ta oriientyry dlia Ukrainy [Intellectual capital in educational institutions of post-industrial content: imperatives of global economic circles and organizations of Ukraine]. Poltava: RVV PUET. (in Ukrainian).

11. Schultz T. W. (1981) Investing in People: the Economics of Population Quality. CA: University of California, Berkeley and Los Angeles.

12. Roos J., Roos G., Dragonetti N., Edvinsson L. (1997) Intellectual capital: Navigating in the New Business Landscape. New York: New York University Press, NY.

13. Corrado C., Hulten C., Sichel D. (2009) Intangible capital and US economic growth. Review of income and wealth, no. 55(3), pp. 661-685.

14. Bueno E., Salmador M. P., Rodriguez O., Catro G. M. D. (2006) Internal logic of intellectual capital: a biological approach. Journal of Intellectual Capital, no. 7(3), pp. 394-405.

15. Sobko O. M. (2014) Intelektual'nyj kapital pidpryiemstva: kontseptualizatsiia-funktsionuvanniarozvytok [Intellectual capital of the enterprise: conceptualization-functioning-development]. Ternopil': Krok. (in Ukrainian).

16. Bontis N. (2001) Assessing knowledge assets: a review of the models used to measure intellectual capital. International Journal of Management Review, no. 3(1), pp. 41-60.

17. Kendiukhov O. V. (2008) Efektyvne upravlinnia intelektual'nym kapitalom [Effective intellectual capital management]. Donets'k: DonUEP. (in Ukrainian).

18. Butnik-Sivers'kyj O. B. (2002) Intelektual'nyj kapital: teoretychnyj aspekt [Intellectual Capital: The Theoretical Aspect]. Intellectual capital, vol. 1, pp. 16-26. (in Ukrainian).

Літвінов О., кандидат економічних наук, дочент, доцент кафедри економіки підприємства та організаиії підприємнищької діяльності, Одеський національний економічний університет (Одеса, Україна).

Нефьодова T., PhD (фінанси), дочент з напряму фінансів, Університет Дофін-Парижу (Париж, Франиія).

\section{Місце маркетингу у формуванні системи класифікаційних ознак інтелектуального капіталу підприємства.}

У статті проаналізовано розвиток ідей щодо складу інтелектуального капіталу та місия маркетингу як його джерела. Ключовою проблемою є визначення переліку ознак, за якими буде формуватися класифікачія компонентів інтелектуального капіталу. На основі критичного аналізу існуючих класифікацій компонентів інтелектуального капіталу сформувалася авторська класифікація за такими ознаками: за джерелами формування; за предметами чи

O. Litvinov, T. Nefedova. Marketing as the source of establishment of pillars of the 23 enterprise intellectual capital 
носіями; за функціональним змістом; залежно від походження; залежно від ступеня керованості; за обсягом; за принципом належності елементів; залежно від стадії ігрового циклу; залежно від динаміки їх зносу; иляхом зберігання інформації, стосовно прочесу створення нових об'єктів; залежно від ступеня ідентифікаиії

Ключові слова: інтелектуальний капітал, елементи інтелектуального капіталу, людський капітал, капітал відносин, організаційний капітал, маркетинг.

Received to the editor June 3, 2019. 